\title{
How The Internet Affects Productivity
}

Mika Hannula, (Email: mika.hannula@tut.fi), Tampere University of Technology, Finland Antti Lönnqvist, (Email: antti.lonnqvist@ tut.fi), Tampere University of Technology, Finland

\begin{abstract}
During the past decade, there has been a lot of research focusing on the Internet's effects on productivity. One of the central themes of this research has been the productivity paradox. Productivity paradox is a phenomenon in which investments in the use of information technology have not resulted in productivity improvements. The objective of this paper is to present the conclusions that this extensive research of the past few years has arrived at concerning the Internet's effects on productivity. This paper also includes a practical example which illustrates how the use of the Internet might result in very high productivity improvements by redesigning the entire business model.
\end{abstract}

In the literature, the research results on the issue are conflicting. Some researchers have not found any evidence that would suggest that the use of the Internet increases productivity. However, there are several success stories that imply that the Internet could be an important tool in improving productivity or overall performance of a firm. In addition, it seems that in some cases the productivity paradox has occurred because of defective or unsuitable productivity measures, or even because of conceptual confusions.

The key finding of this paper is that the use of the Internet may or may not increase productivity, depending on the way it is used. From the managerial perspective, there are also many other reasons for using the Internet, such as improved customer service or competitive pressure. However, a better customer service means better value for a customer. For a firm this usually means better productivity. To conclude, it seems evident that successful investments in internet technology should lead to better productivity and the greatest productivity improvements are attainable when the Internet is used to create entirely new business models.

\section{Introduction}

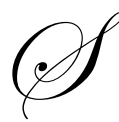

ince the beginning of the Internet era, there have been high expectations regarding the use of the Internet to increase productivity. There have also been concerns that the misuse of the Internet would decrease productivity. These questions have resulted in a boom in Internet - and productivity-related research. The EBSCO $^{1}$ article database search made May $11^{\text {th }} 2001$ found 762 articles with the entries INTERNET and PRODUCTIVITY. This is a very high number, considering that the Internet has not even been around for a long time. This paper aims to conclude what this extensive research of the past few years has discovered regarding the Internet's effects on productivity. It also includes a practical example, which is presented in order to illustrate how the use of Internet might improve productivity when the business model is totally redesigned. The discussion in this paper is limited to the micro level, i.e., macro-level consideration is not included in the paper.

Readers with comments or questions are encouraged to contact the authors via email. What is productivity?

The success of organizations depends on many factors, such as cost efficiency, innovations, growth, and especially the value it can produce for its customer. All these affect productivity improvement and thereby profita-

\footnotetext{
${ }^{1}$ EBSCO is a database which includes journal articles from various scientific disciplines. For more information, see the Internet: http://www.epnet.com/about.html.
} 
bility, which are vital for any organization. However, from the managerial perspective, profitability is usually seen as the most important success factor, while productivity is seen as only one among many other important factors.

Productivity can be defined simply as output divided by the input that is used to generate th e output:

$$
\text { Productivity }=\frac{\text { Output }}{\text { Input }}
$$

Output consists of products and services and input consists of materials, labor, capital, energy, etc. It is important to notice that in addition to the quantity of the output also the quality of the output matters here. This is also valid when measuring the input component of the productivity ratio. Total productivity of any process can be expressed very simply: it is the total output divided by the sum of all inputs. In practice, total productivity measurement is not that easy. Rather complicated methods are usually needed for the purpose. Despite this, productivity improvement is still the most important factor, being essential for long-run business success and profitable operation.

The role of productivity improvement in business can be approached by considering how the unit output ${ }^{2}$ of the productivity ratio is determined in everyday business. Actually, the question should be: "Who determines the output of any business process?" The answer is: "The customer". The value of any product or service is determined by the customer being interested or being not interested in the product or the service.

The term value is used in this context in a very broad sense. Although the most common meaning of value is monetary worth, the connection with money is often rather remote (See Lucas 1999, p. 4). In the context of this paper, the value for the customer defines the unit output of any product or service. Thus, total productivity of any business is actually very much a customer-oriented concept.

Productivity can be approached at different levels. The measurement levels can be roughly categorized into macro and micro level. Macro level includes international, national economy, and industrial levels, while micro level includes the firm level and all the levels below it (see Hannula 1999, p.20). In this paper the discussion is limited mainly to the micro level, where investment decisions are, or at least should be, based on profitability.

\section{Productivity Paradox}

One of the recent interesting research topics related to productivity has been the productivity paradox. Productivity paradox refers to the phenomenon where investments in information technology (IT) have not resulted in increased productivity (See e.g. McCune 1998, Lucas 1999 or Holopainen et al. 1999). The Internet is considered so far to be one of the most significant achievements of IT. Thus, the productivity paradox is a relevant framework for considering the effects of the Internet on productivity at firm level.

Various explanations for the productivity paradox can be found in the literature. They vary from incorrect research approach to findings according to which IT is really detrimental to productivity improvement. According to Brynjolfsson (1993), there are four main causes for productivity paradox:

1. Measurement error: Productivity of white-collar work cannot be measured properly using traditional productivity measures.

2. Lags: There may be a time lag between IT investment and productivity improvement, making it difficult to perceive the improvement.

3. Redistribution: IT investment may redistribute activities among firms, i.e., investment in IT rearranges the shares of the pie without making it any bigger.

4. Mismanagement: Managers have not succeeded in implementing and using IT. Instead, the systems are inefficient.

\footnotetext{
${ }^{2}$ Unit output refers here to the output that is due to one product or service produced by the firm.
} 
The first two points suggest that IT investments really increase productivity but researchers have not been able to measure it. In other words, the research approach has been incorrect. The second two points state that IT investments have not increased productivity and offer explanations of why that is so. The causes presented above will be further discussed later in this paper.

In addition to the explanations above, other causes have also been suggested. Most of them consider different measurement problems. A very popular one deals with the commonly known problem of statistical studies, where numerous cases are processed in aggregated form. Because of this, successful and unsuccessful cases are mixed and it is difficult or even impossible to reach relevant conclusions.

\section{How does the Internet affect productivity?}

The Internet has a lot of characteristics that can be utilized to improve productivity. Just to name a few, there are no time or space limitations for accessing the Internet, finding information can be easy and efficient, and it is possible to transfer various kinds of information in electronic form. Properties like these have led to totally new markets, business models, and processes.

On the other hand, there has also been concern that especially labor productivity ${ }^{3}$ would decrease because employees may spend a lot of time surfing Internet sites that are not job related. This way the output per work hour would suffer. However, according to a survey conducted in 1995, 70 percent of U.S. managers felt that using the Internet increases labor productivity, while 15 percent felt that it decreases labor productivity (Hayes 1995). Opposite claims have been presented by Gartner Group, which estimates that U.S. businesses lose as much as 26 million manhours a year to online game playing by employees (Anon. 1998). Of course, the validity of the results of any survey always needs careful evaluation. Nevertheless, the results of empirical studies in this matter seem to be inconsistent.

There are two main uses for the Internet in business:

1. E-commerce: This refers to buying and selling that occurs on the Internet (Teollisuus ja Työnantajat 2000, p. 3). In e-commerce the e-business processes are not fully integrated into the core business processes of the firm.

2. E-business: This refers to all business possibilities that electronic data transfer offers. These include such possibilities as e-commerce, controlling production and inventory via the Internet, transferring data to business partners' or authorities' information systems, and finding new customers (Teollisuus ja Työnantajat 2000, p. 3). Mature utilization of e-business can finally lead to integrated e-network economy, where partners are connected via the Internet to each other. In this model the partners are able to concentrate on their core business while other business processes are outsourced to other partners in the network (Tekes 2000, p. 9).

According to a survey conducted by the Confederation of Finnish Industry and Employers in spring 2000, 95 percent of Finnish industrial companies used some form of e-business and 80 percent used e-commerce (Teollisuus ja Työnantajat 2000, p. 4). The most common forms of e-business are transferring data between business partners and ordering goods via the Internet. In addition, e-business is applied in controlling production, logistics, and inventory, and it is also used in various functions of marketing and sales. (Teollisuus ja Työnantajat 2000, p. 6) There seem to be large variations between countries. According to another recent survey, only 14.7 percent of the manufacturing firms in the U.S. are using the Internet to sell their products (Anon. 2001, p.18).

As mentioned, e-commerce is just one way of utilizing the Internet for productivity improvement. Table 1 shows how companies use Internet technology to boost productivity in different business processes. It shows both

${ }^{3}$ Labor productivity $=\frac{\text { Output }}{\text { Labor input }}$ 
practical examples and the payoff that they have caused. The examples illustrate well the many possibilities to improve business performance that the Internet generates. It is worth noticing that many e-business initiatives do not directly aim at increasing productivity. Most initiatives aim at cost reduction or better profit. If successful, both objectives lead to productivity improvement.

Table 1: How companies use Internet technology to boost productivity at every stage of the business process. (Reingold et al. 2000)

\begin{tabular}{|c|l|l|}
\hline & \multicolumn{1}{|c|}{ Example } & \multicolumn{1}{|c|}{ Payoff } \\
\hline INNOVATION & $\begin{array}{l}\text { Royal Dutch / Shell's "GameChanger" teams use } \\
\text { the Net to generate new business ideas }\end{array}$ & $\begin{array}{l}\text { New "Light Touch" oil discovery me- } \\
\text { thod found 30 million barrels }\end{array}$ \\
\hline COLLABORATION & $\begin{array}{l}\text { Ocean Spray's extranet assesses cranberry quality } \\
\text { immediately and helps growers get better prices }\end{array}$ & $\begin{array}{l}\text { Growers get higher profits; Ocean } \\
\text { Spray cuts waste and boosts productivi- } \\
\text { ty }\end{array}$ \\
\hline DESIGN & $\begin{array}{l}\text { Honeywell uses the Net to help fashion a custo- } \\
\text { mized prototype of anything from a fan blade to } \\
\text { a golf club head }\end{array}$ & $\begin{array}{l}\text { Design time cut from six months to 24 } \\
\text { hours }\end{array}$ \\
\hline PURCHASING & $\begin{array}{l}\text { Ford's AutoXchange creates a massive online } \\
\text { trading bazaar for its 30,000 suppliers }\end{array}$ & $\begin{array}{l}\text { Could save as much as } \$ 8 \text { billion in } \\
\text { first few years }\end{array}$ \\
\hline MANUFACTURING & $\begin{array}{l}\text { BP Amoco, using Net technology from Honey- } \\
\text { well, can quickly identify plant inefficiencies }\end{array}$ & $\begin{array}{l}\text { Yields 2\% per day productivity loss in } \\
\text { Grangemouth, Scotland, refinery }\end{array}$ \\
\hline LOGISTICS & $\begin{array}{l}\text { Cement maker Cemex uses a Net-based truck } \\
\text { dispatch system to speed deliveries to customers }\end{array}$ & $\begin{array}{l}\text { Cement delivered within 20 minutes, } \\
\text { down from 3 hours }\end{array}$ \\
\hline MARKETING & $\begin{array}{l}\text { Weyerhaeuser uses the Net to weed } \\
\text { least valuable customers at Marshfield (Wis.) } \\
\text { door plant }\end{array}$ & $\begin{array}{l}\text { Boosted the plant's return on net assets } \\
\text { from -2\% in 1994 to 27\% in 1999 }\end{array}$ \\
\hline SERVICE & $\begin{array}{l}\text { GE Power Systems lets customers use the Net to } \\
\text { compare the performance of its turbines against } \\
\text { other GE turbines in the market }\end{array}$ & $\begin{array}{l}\text { Turbine productivity expected to rise } \\
\text { by 1\% to 2\% annually }\end{array}$ \\
\hline
\end{tabular}

In some examples in Table 1, increased customer service is mentioned as one of the key benefits. According to the survey conducted by the Confederation of Finnish Industry and Employers, 80 percent of the Finnish industrial companies felt that the use of e-business increased customer satisfaction and more than two thirds stated that their productivity and profitability had risen as a result of e-commerce (Teollisuus ja Työnantajat 2000, p. 4). Better service to a customer also means better value of the products. Further, this means better unit output for the products and the services of the firm. Thus, successful initiatives to improve customer service improve productivity if the input invested is lower compared with the achieved improvements. It is difficult to measure this kind of productivity improvement but the logic seems to be clear.

According to the PAYOFF column, the examples shown in the table above are all very successful. However, it is not self-evident that all companies will succeed in their Internet strategies. McCune (1998) has compiled some themes from research and practice regarding how computers affect productivity. These can also be used as guides for using the Internet to increase productivity:

- $\quad$ True productivity increase is achieved not by trying to make small improvements, but when companies reinvent the way they work.

- $\quad$ Technological improvement should be seen as a continuous process, not as a one-time project.

- $\quad$ Technology should be used as a tool to build better relationships with partners.

- $\quad$ Computers improve productivity through quality, rather than quantity, of work.

McCune (1998) has also compiled some pitfalls in technology that may affect productivity negatively: 
- $\quad$ Computers, especially the Internet, contribute to information overload.

- $\quad$ Use of e-mail has created very high expectations of getting an almost instant reply.

- $\quad$ Learning new technologies and computer software takes time.

- $\quad$ Technological advancements may make the product too advanced, i.e., too many features make the product too complicated and thus harder to use.

The authors' own experiences tend to be in agreement with McCune. These points show that unless the use of IT is carefully planned and managed, there are many things that can go wrong. According to Cook (1999), it is important that IT be managed, not just purchased.

\section{Productivity paradox and Internet investments}

As was discussed in the previous chapter, the Internet has a lot of potential in increasing productivity at the firm level. However, according to the productivity paradox, IT investments do not always lead to better productivity. In this chapter of the paper, the possible explanations for the productivity paradox are discussed. The list by Brynjolfsson (1993), which was presented earlier in this paper, is used as a framework.

\section{Measurement error}

Brynjolfsson (1993) states that productivity of white-collar work cannot be measured properly using traditional productivity measures. It is true that white-collar productivity is difficult to measure properly by traditional productivity measures. However, this is not the only measurement problem in the case of productivity measurement. First, total productivity should be used instead of labor productivity in studying productivity paradox at the firm level. In IT investment, labor input is usually substituted with a sophisticated IT system. However, this does not tell us anything about the change in total productivity. Thus, labor productivity - being white-collar, blue-collar, or even a combination of both - is too narrow an instrument for studying productivity paradox. Second, productivity is often confused with profitability. Now it is important to emphasize the basic connection between productivity improvement and profitability: Productivity improvement is the precondition for long-run profitability of business processes. Thus, productivity improvement as such does not guarantee any improvement in profitability. In fact, a steady profitability level can be an indication of long-run improvement in profitability.

Generally speaking, the measurement error explanation suggests that IT investments really increase productivity, but researchers have not been able to measure it. In the real world, there are different ways to measure productivity (Hannula 1999, p. 21-23):

- $\quad$ At the macroeconomic level, economists use labor productivity as the most important productivity measure. Comparative analyses concerning productivity at the national level or in industry are usually based on ratios, where the number of employees is used as the nominator.

- $\quad$ At the firm level, accountants, managers, engineers, and also economists have proposed various productivity measures and measurement methods. Productivity measures must be chosen so that they serve the managerial needs of the particular firm and measurement situation.

Total productivity would take into account the contribution of different inputs, but it is not commonly used at the firm level. Traditional productivity measures are compromises between different needs. In everyday performance measurement, other performance factors than productivity are often more important. For example, the quality aspect is usually given a lot of attention. At the firm level, productivity measurement is usually kept more quantity oriented than quality oriented. This is because of the unsophisticated measurement methods, not because of the productivity concept itself.

According to Lewis (1996), productivity is not even important in some cases. What should be measured according to him is effectiveness. Lewis offers an example of a Hollywood screenwriter whose productivity is measured in words typed per minute. In that case, the quality of the screenplay counts, not the pace at which it is written. This is a typical example of poor productivity measurement. The effectiveness of the output of a writer contributes to the productivity of the writing process, since the customer finally defines the writer's unit output. The effective- 
ness of the text written by the writer is without any doubt noticed by the customer.

To conclude, measurement error seems to be a very potential cause of productivity paradox, at least when approached at the firm level. Valid total productivity measures should be used in these studies, but this is rather complicated and comparable measurement results from different business processes are difficult to achieve.

\section{Lags}

There may be a time lag between IT investment and productivity improvement, making it difficult to perceive the improvement. This is a well-known problem in most statistical research projects. The relationship between IT investments and productivity could perhaps be determined using cross correlation (See Holopainen and Pulkkinen 1999, p. 237). Cross correlation describes how two time series are correlated with each other and shows what the delay is between the cause and effect. Although the causality between factors is difficult to prove, the main problem with cross correlation is the method's complicatedness. The formula itself is not particularly complicated. The problems arise when there are multiple dependencies with different delays between multiple factors. Nevertheless, if a dependency includes a significant delay, cross correlation is the only method possible for verifying the relationship.

The problem of time lag is well known not only in statistical research, but also in accounting. It is difficult to predict when the expected benefit from any investment will be realized. When productivity paradox is studied at the firm level, this problem has to be solved somehow. If the same model is used for different cases in one single study, it is obvious that the estimation of the time lag will not be perfect in every case.

\section{Redistribution}

IT investment may redistribute activities among firms, i.e., investment in IT rearranges the shares of the value pie without making it any bigger. Hamel (2001) states that the Internet creates productivity gains, but profit margins will shrink. This is caused by at least two things. First, productivity gains that are gained by Internet use are distributed among many sectors, such as consultants, IT hardware and software manufacturers, and Internet connection providers. Second, competition between companies will increase because customers can easily compare prices. This will result in decreased profitability. Hamel also predicts that companies' strategies will become more similar. This prediction is in line with the view, which states that the next step after e-business is e-network economy in which partners concentrate on their core business while not-so-important business processes are outsourced (Tekes 2000, p. 9).

Hamel's first explanation is interesting from the macro perspective. He states that productivity gains are distributed among many actors. Although productivity improvement might not be recognized from the perspective of one actor, it should be found using macro-level data. Nevertheless, redistribution of productivity gains by Internet needs further investigation.

\section{Mismanagement}

Mismanagement means that IT investments have not increased productivity because managers have not succeeded in implementing and using IT. It is easy to get overly enthusiastic as regards what the Internet promises. Some managers have made IT investment decisions based on "a gut feel" intuition (Cook 1999). However, Internet investments should be treated like any other long-time investment. According to Cook (1999), many business executives feel productivity improvement is achievable through the proper management of IT investments. Cook concludes that "information technology must be managed, not just purchased, and the metric definition sequence should be targeted to business alignment followed by productivity measures". The measures should be relevant to the organization, which is to be served by the newly purchased technology, and measurable and accurate within reason.

To conclude, there can be various reasons for productivity paradox. Depending on the study and its research approach, any of the explanations discussed above can be the cause. The measurement problem or the confu- 
sion between productivity improvement and profitability of business processes seem to be the most obvious cause of productivity paradox. In fact, if this is the case, the whole idea of productivity paradox can be, frankly speaking, false. There have been numerous cases when productivity paradox has not occurred (See Table 1 in this paper) and the investments in Internet technology have resulted in increased profitability. It is most probable that productivity in these cases has also improved, because otherwise it would be very difficult to explain the improved profitability.

\section{Using the Internet to increase grocery productivity}

Internet technology can affect the productivity ratio through the output component, the input component, or both at the same time. Traditionally, investments in information technology have been justified by cost reductions, i.e., a reduction in the input component. However, a significant impact on the productivity of a business process can be achieved through the output component of the productivity ratio. In order to show this, a simple example is presented in this chapter.

The ECOMLOG research program at the TAI Research Centre at Helsinki University of Technology studies, among other things, a new type of grocery business (source: ECOMLOG research project's Internet site). "Egrocery" is used here to illustrate how dramatically the use of the Internet can affect productivity. The key is a totally new business model for groceries, not the use of the Internet itself. Productivity improvements are compared with common supermarkets.

The e-grocery of the future is actually an automated distribution center, where a specialist does the order picking for the customer. The customer gives the order via the Internet. Groceries are delivered twice a week to a customer's reception box, which resembles a refrigerated mailbox (Kämäräinen et al. 2001a and 2001b).

Compared to the traditional supermarket, the e-grocery is a lot more efficient. First, customers save a lot of time, energy, and money when they do not have to drive to the supermarket. This is also of significance from an environmental standpoint because exhaust gas quantities would decrease. According to Punakivi and Holmsröm (2000), there is a 54 to 93 percent reduction potential compared with the mileage in the current situation, depending on the home delivery service concept. In addition to the energy productivity perspective, because of the time saved the value for the customer is much higher than in the traditional shopping model.

The second important point is that order picking is much more efficient in the e-grocery. When done by experts, the picking pace is faster because the distribution center is especially designed for fast picking. In addition, there are no other customers who would get in the way. The labor input needed for the service is lower than in the supermarket and the space utilization will be more efficient. If automation were utilized, the savings could be even bigger. (Kämäräinen et al. 2001b)

The e-grocery concept includes many other characteristics in addition to those mentioned above. The majority in productivity improvement come from the new supply chain. The firm operating an e-grocery can operate more efficiently. The value for the customer is also higher, since he or she needs dramatically less time to do the shopping. Thus, the e-grocery concept provides more output with less input. This is productivity improvement.

\section{Discussion}

There have been a lot of conflicting research results on the effects of Internet on productivity. Some researchers have not found any evidence that would support the idea that use of the Internet increases productivity. On the other hand, there are several success stories that imply that the Internet could be an important tool in improving productivity. One of the main conclusions of this paper is that the measurement problem is one of the most obvious reasons for the productivity paradox. Actually, it is possible that the paradox itself is based on false measurement methods and conceptual misunderstandings.

Another main conclusion of this paper is that the use of the Internet may or may not increase productivity depending on the way it is used. It seems that the greatest productivity improvements are obtained when the Internet 
is used to create entirely new business models. New business models can provide better value for the customer in addition to cost reductions. This is in line with the fact that new technology as such does not guarantee competitive advantage because any competitor can achieve it. New technology like Internet - or any other information technology - must be seen as an enabler which can be applied to implement new business processes and models which give true competitive advantage. Such competitive advantage gives faster productivity improvement than what any competitor can achieve.

Nowadays, the use of the Internet may no longer be an option for some companies. If all the major competitors or customers use the Internet, the company may have no choice but to start using it also. As the examples in the previous chapters showed, from the managerial perspective the Internet is used for many other purposes than just to increase productivity. Other uses for the Internet include improving customer service or profitability. However, if successful, these investments do not only give a better profit level or better customer service, but also lead to productivity improvement.

The productivity paradox has not yet been properly solved. Many of the issues in the productivity paradox are related to measurement and productivity measurement in particular. Therefore, further studies should be targeted in the following areas:

- $\quad$ Redistribution of productivity gains. Case studies should be carried out in addition to statistical studies. The research problem here is how the productivity gains are distributed between different actors, such as consultants and IT equipment manufacturers

- The impact of Internet on white-collar work. How does Internet and email affect time spending and the effectiveness of work?

- $\quad$ Productivity studies which take into account the time lag between investment and the possible advantages. If the case study approach is used, the time lag should be studied case by case.

- $\quad$ The control of IT implementation at the firm level. There seems to be a lack of measures to control that IT is used efficiently and effectively as planned (making it possible to manage IT use).

At the firm level, IT investments are, or at least should be, evaluated through profitability. Most evaluation methods used in firms are based on profitability measures. This does not diminish the value of the productivity research in this area. However, since appropriate productivity measures are not commonly available, productivity research may be difficult to approach at the firm level. It is clear that other performance factors in addition to productivity must be considered.

For the future, the next challenge or opportunity seems to be wireless Internet and the mobile business (mbusiness) which wireless internet technology enables. In that era, there will probably again be both winners and losers. It would seem that, like in the Internet, the biggest winners will be those who use the technology to transform their business processes in a way that will result in productivity improvements for themselves as well as for their customers.

\section{References}

1. Anon. (1998) Preventing a productivity drain, Nation's business, March, pp. 56.

2. Anon. (2001) Benchmarks for U.S. Manufacturing Productivity, Material Handling Management, April, pp. 18.

3. Brynjolfsson, E. (1993) The productivity paradox of information technology, Communications of the ACM, December, pp. 67-77.

4. Cook, B. (1999) Paradoxically speaking. Increased IT spending and the lack of productivity improvements. Inform, May, pp. 40.

5. ECOMLOG research project's Internet site, (http://www.tai.hut.fi/ecomlog/) (Site visited May $11^{\text {th }} 2001$.)

6. Hamel, G. (2001) Edison's Curse. Fortune, March 5, pp. 175-178.

7. Hannula, M. (1999) Expedient Total Productivity Measurement. Espoo, The Finnish Academy of Technology. $179 \mathrm{p}$. 
8. Hayes, M. (1995) Working Online, Or Wasting Time? Information Week, 5/1, Issue 525, pp. 38-45.

9. Holopainen, S., Lillrank, P. \& Paavola, T. 1999. Tietotekniikan linkki liiketoimintaan. Keuruu, Otavan kirjapaino, $183 \mathrm{p}$.

10. Holopainen, M., Pulkkinen, P. (1999) Tilastolliset Menetelmät. Porvoo, WSOY-Kirjapainoyksikkö, 301 p.

11. Kämäräinen, V., Saranen, J., Holmström, J. (2001a) The reception box impact on home delivery efficiency in the e-grocery business, forthcoming in The International Journal of Physical Distribution and Logistics Management.

12. Kämäräinen, V., Småros, J., Jaakola, T., Holmström, J. (2001b) Cost-effectiveness in the e-grocery business, International Journal of Retail \& Distribution Management, Vol. 29, No. 1.

13. Lewis, B. 1996. IS Productivity Paradox Means We Should Be Measuring Effectiveness, Infoworld, February 26 , pp. 61.

14. Lucas, H. C. Jr. (1999) Assessing the Value of Investing in IT. New York, Oxford University Press, 225 p.

15. McCune, J. C. (1998) The Productivity Paradox. American Management Association International, March, pp. 38-40.

16. Punakivi, M., Holmström, J. (2000) e-Grocery home delivery -a step towards Green Logistics, July.

17. Tekes. (2000) Elektronisesta kaupasta e-liiketoimintaan. Ed. by Järvelä, P., Tinnilä, M. 113 p.

18. Teollisuus ja Työnantajat (The Confederation of Finnish Industry and Employers). (2000) Tehoa tietoverkoista. $16 \mathrm{p}$.

Notes 